Original Research

\title{
Photosynthetic Responses of Tomato Leaves to Salt and Cadmium Stresses: Growth and Chlorophyll a Fluorescence Kinetic Analyses
}

\author{
Fatma Gharbi ${ }^{1 *}$, Lobna Zribi ${ }^{1}$, Alia Ben Daly ${ }^{1}$, \\ Saloua Rejeb², Belgacem Hanchi ${ }^{1}$ \\ ${ }^{1}$ Université de Tunis El Manar, Faculté des Sciences de Tunis, Tunis, Tunisia \\ ${ }^{2}$ Institut National de Recherche en Génie Rural Eaux et Forêts, Ariana, Tunisia
}

Received: 14 September 2017

Accepted: 7 December 2017

\begin{abstract}
This study investigated the effects of salinity $(\mathrm{NaCl})$ and cadmium $(\mathrm{Cd})$ on leaf growth and photosynthetic parameters of tomato plants (Solanum lycopersicum cv. Rio Grande). $\mathrm{Cd}$ and $\mathrm{NaCl}$ treatments considerably reduced leaf dry matter and leaf area of tomato plants. Stomatal conductance decreased significantly with increased $\mathrm{NaCl}$ and $\mathrm{Cd}$ in the growth medium, with the decrease occurring at an early stage under $\mathrm{Cd}$ treatments. For the fluorescence parameters, there was no significant difference in the maximum quantum efficiency of PSII $\left(\mathrm{F}_{\mathrm{v}} / \mathrm{F}_{\mathrm{m}}\right)$ for either type of stress. However, the quantum yield of PSII photochemistry $\left(\Phi_{\text {PSII }}\right)$, photochemical quenching $\left(\mathrm{q}_{\mathrm{p}}\right)$, and the intrinsic efficiency of PSII $\left(\Phi_{\text {exc }}\right)$ decreased significantly under both $\mathrm{NaCl}$ and Cd treatments. Decreases in $\Phi_{\mathrm{PSII}}, \mathrm{q}_{\mathrm{p}}$, and $\Phi_{\text {exc }}$ were coupled with a significant increase in non-photochemical quenching (NPQ), and the highest NPQ was obtained in NaCl-treated plants. The correlation between electron transport rate (ETR) and stomatal conductance showed that stomatal closure is associated with a down-regulation of ETR, which is compensated by an increase in non-photochemical quenching.
\end{abstract}

Keywords: cadmium, chlorophyll fluorescence, salinity, stomatal conductance, tomato

\section{Introduction}

Salinity is one of the major environmental stresses, limiting crop productivity and negatively affecting physiological processes in a variety of species [1-2]. Heavy metal (HM) pollution is also a major source of stress

*e-mail: fatmagharbi@yahoo.com and one that has been aggravated by rapid urbanization, industrialization, and agricultural pollution, including impurities from fertilizers and irrigation with wastewater [3]. Of all the HMs, cadmium (Cd) is the most abundant and of the highest concern because it is readily taken up by crop plants [4-5]. Both $\mathrm{Cd}$ and salt stresses affect plant growth and development by inducing physiological dysfunctions. Excessive $\mathrm{Cd}$ in soil can cause many toxic symptoms in plants such as reduced growth and 
disturbances in mineral nutrition and carbohydrate metabolism, and therefore may strongly reduce biomass production [6-8]. Decreased biomass due to $\mathrm{Cd}$ toxicity could be a direct consequence of inhibited chlorophyll synthesis and photosystem II (PSII) efficiency [9-10]. Salinity could also have a similar effect. The physiological processes affected by salinity include changes in plant growth [11], membrane permeability [12], mineral distribution [13], reduction in chlorophyll content [1415], and decreased efficiency of photosynthesis [16-17]. Understanding the physiological mechanisms of various stress factors is critical in predicting the disturbances that influence plant growth and productivity. Photosynthesis is one of the most important metabolic processes in plants and its performance is greatly affected by environmental constraints, making photosynthetic measurements an important component of plant stress studies [18]. In order to determine photosynthetic damage as caused by environmental stresses, chlorophyll fluorescence (ChlF) can be used to detect the impact of such stresses on plants [19]. Measuring the yield of ChlF can provide information about changes in the efficiency of photosynthesis and heat dissipation [20]. Photosynthetic efficiency of PSII, both in the light $\left(\Phi_{\text {PSII }}\right)$ and in a dark-adapted state $\left(\mathrm{F}_{\mathrm{v}} / \mathrm{F}_{\mathrm{m}}\right)$ are the most widely used Chl fluorescence measuring parameters in plant investigations [21-22]. ChlF has been used to measure salt-tolerance characteristics of rice [23], grapevines [24], and Crithmum maritimum [25]. In addition, ChlF-based methods have been developed to measure heavy metal effects [26].

$\mathrm{Cd}$ has been shown to induce change in ChlF and photosynthetic activities of Zea mais [9], Elsholtzia argyi [10] and wheat cultivars [27]. Environmental stresses such as salt [28-31] and cadmium [32-35] can also affect photosynthetic pigments and inhibit photosynthesis. It was shown that PSII efficiency depends on pigment concentration and structure [36]. Chlorophyll concentration varies according to environmental conditions and some pigments such as carotenoids, which have been reported to play a direct role in NPQ [37], and are involved in photosynthesis and photoprotection mechanisms [38-41]. In Tunisia, tomatoes are one of the most important horticultural crops. They cover more than 120,000 ha and are exposed to many adverse environmental stress factors [42]. In this study, we selected two of the most prevailing stresses affecting agricultural soil in Tunisia [43] and investigated the response of tomato plants (Solanum lycopersicum cv. Rio Grande), a variety that plays an important role in the Tunisian agricultural economy [44]. The objectives of our study were: (i) to evaluate the effects of $\mathrm{NaCl}$ and $\mathrm{Cd}$ on plant growth, chlorophyll content, and functionality of the photosynthetic apparatus and (ii) to identify the most relevant ChlF parameters of photosynthetic disturbance in tomatoes under salt and cadmium stresses.

\section{Materials and Methods}

\section{Experimental Design}

The study included two treatments: salt and cadmium stresses conducted under the same controlled conditions in a culture chamber over different periods. Tomato (Solanum lycopersicum cv. Rio Grande) seeds were germinated in trays filled with peat. The average temperature was $28 \pm 2^{\circ} \mathrm{C}$ and relative humidity was $90 \%$. After 20 days (d), tomato seedlings at the second true leaf stage were transferred to plastic pots (one plant per pot) containing peat. The environmental conditions were $28 / 17^{\circ} \mathrm{C}$ (day/night) temperature, $16 \mathrm{~h}$ light $(450 \mu \mathrm{mol}$ $\left.\mathrm{m}^{-2} \mathrm{~s}^{-1}\right)$ and $60-70 \%$ relative humidity. Plants were grown under non-stress conditions for 13 days. When plants were at the third true leaf stage (day 34), cadmium and salt treatments were initiated. Sodium chloride $(\mathrm{NaCl})$ and cadmium chloride $\left(\mathrm{CdCl}_{2}\right)$ were added to deionised water to provide final concentrations of 0 (control), 25, 50, 100, 150, and $200 \mathrm{mM} \mathrm{NaCl}$, and $0,1,2.5,5$, and $10 \mathrm{mM} \mathrm{Cd}$. Both $\mathrm{NaCl}$ and $\mathrm{Cd}$ concentrations were imposed incrementally every day until final concentrations were reached. The plants were grown for $28 \mathrm{~d}$ under salt stress and $12 \mathrm{~d}$ under cadmium stress. Irrigation was applied twice a day. The experiment was carried out with six replications for both $\mathrm{NaCl}$ and $\mathrm{Cd}$ treatments.

\section{Stomatal Conductance and Chlorophyll Fluorescence Measurements}

Stomatal conductance (Gs) was determined using a Delta $\mathrm{T}$ model $\mathrm{P}_{4}$ porometer according to Monteith et al. [45]. Chlorophyll fluorescence emission from the upper surface of the leaves was measured by a modulated fluorimeter (Mini PAM Photosynthesis Yield Analyser, Walz, Effeltrich, Germany). Selected leaves to measure stomatal conductance were used for fluorescence measurements. The initial $\left(\mathrm{F}_{0}\right)$ and maximum fluorescence $\left(\mathrm{F}_{\mathrm{m}}\right)$ emissions were assessed in leaves after $30 \mathrm{~min}$ of dark adaptation, and the maximum quantum efficiency of PSII was calculated as $\mathrm{F}_{\mathrm{v}} / \mathrm{F}_{\mathrm{m}}=\left(\mathrm{F}_{\mathrm{m}}-\mathrm{F}_{0}\right) / \mathrm{F}_{\mathrm{m}}$. Next, the leaves were continuously illuminated with a white actinic light in order to measure $\mathrm{F}_{\mathrm{s}}$ and $\mathrm{F}_{\mathrm{m}}$ (steady-state and maximum fluorescence yield in light-adapted leaves, respectively). The parameter $\mathrm{F}_{0}{ }_{0}$ (minimum fluorescence in the light-adapted state) was estimated following Baker and Rosenqvist [46]. Non-photochemical quenching of fluorescence (NPQ), which is proportional to the rate constant of thermal energy dissipation [47], was calculated as NPQ $=\left(\mathrm{F}_{\mathrm{m}}-\mathrm{F}_{\mathrm{m}}{ }_{\mathrm{m}}\right) / \mathrm{F}_{\mathrm{m}}$. The coefficient of photochemical quenching $\left(\mathrm{q}_{\mathrm{p}}\right)$ was calculated as $\left(\mathrm{F}_{\mathrm{m}}{ }_{\mathrm{m}}-\mathrm{F}_{\mathrm{s}}\right) /\left(\mathrm{F}_{\mathrm{m}}{ }_{\mathrm{m}}-\mathrm{F}_{0}{ }_{0}\right)$ [48]. The intrinsic efficiency of open PSII $\Phi_{\text {exc }}$ was calculated as $\mathrm{F}^{\prime} / \mathrm{F}^{\prime}$. The quantum yield of PSII electron transport, $\Phi_{\text {PSII }}[49-50]$, was calculated as $\Delta \mathrm{F} / \mathrm{F}_{\mathrm{m}}{ }_{\mathrm{m}}=\left(\mathrm{F}_{\mathrm{m}}{ }_{\mathrm{s}}-\mathrm{F}_{\mathrm{s}}\right) / \mathrm{F}_{\mathrm{m}}{ }_{\mathrm{m}}$ where $\Delta \mathrm{F}=\mathrm{F}_{\mathrm{m}}{ }_{\mathrm{m}}-\mathrm{F}_{\mathrm{s}}[51] . \Phi_{\mathrm{PSII}}$ is used to calculate the linear electron transport rate (ETR) according to Krall 
Table 1. Dry matter (DM), leaf area (LA), and pigment contents in tomato leaves after exposure to 28 days $\mathrm{NaCl}$ or 12 days $\mathrm{Cd}$ at different concentrations.

\begin{tabular}{|c|c|c|c|c|c|c|c|}
\hline Treatments & & DM & LA & Chlorophyll a & Chlorophyll b & Carotenoids \\
\hline$(\mathrm{mM})$ & & $(\mathrm{g})$ & $\left(\mathrm{dm}^{2} \cdot \mathrm{plant}^{-1}\right)$ & \multicolumn{3}{|c|}{$\left(\mathrm{mg}^{-1} \mathrm{~g}^{-1} \mathrm{FW}\right)$} \\
\hline $\mathrm{NaCl}$ & 0 & $13.42 \mathrm{a}$ & $35.82 \mathrm{a}$ & $1.06 \mathrm{a}$ & $0.6 \mathrm{a}$ & $0.41 \mathrm{~d}$ \\
\hline & 25 & $14.73 \mathrm{a}$ & $42.43 \mathrm{a}$ & $0.96 \mathrm{~b}$ & $0.50 \mathrm{~b}$ & $0.44 \mathrm{~d}$ \\
\hline & 50 & $12.40 \mathrm{a}$ & $36.28 \mathrm{a}$ & $0.80 \mathrm{c}$ & $0.49 \mathrm{~b}$ & $0.48 \mathrm{c}$ \\
\hline & 100 & $11.70 \mathrm{a}$ & $26.48 \mathrm{~b}$ & $0.72 \mathrm{~d}$ & $0.42 \mathrm{c}$ & $0.51 \mathrm{c}$ \\
\hline & 150 & $7.15 \mathrm{~b}$ & $18.86 \mathrm{bc}$ & $0.69 \mathrm{~d}$ & $0.30 \mathrm{~d}$ & $0.59 \mathrm{~b}$ \\
\hline & 200 & $5.80 \mathrm{~b}$ & $11.84 \mathrm{c}$ & $0.58 \mathrm{e}$ & $0.22 \mathrm{e}$ & $0.66 \mathrm{a}$ \\
\hline & 0 & $12.70 \mathrm{a}$ & $33.84 \mathrm{a}$ & $1.03 \mathrm{a}$ & $0.58 \mathrm{a}$ & $0.38 \mathrm{a}$ \\
\hline & 1 & $7.60 \mathrm{~b}$ & $13.00 \mathrm{~b}$ & $0.88 \mathrm{~b}$ & $0.51 \mathrm{~b}$ & $0.32 \mathrm{~b}$ \\
\hline & 2.5 & $3.41 \mathrm{c}$ & $8.60 \mathrm{c}$ & $0.80 \mathrm{c}$ & $0.48 \mathrm{~b}$ & $0.27 \mathrm{c}$ \\
\hline & 5 & $2.80 \mathrm{c}$ & $6.50 \mathrm{~d}$ & $0.75 \mathrm{~d}$ & $0.40 \mathrm{c}$ & $0.24 \mathrm{~d}$ \\
\hline
\end{tabular}

Values are means of six replications. Data labelled with different letters are significantly different $(\mathrm{P}<0.05)$.

and Edwards [52]. ETR $=\Delta \mathrm{F} / \mathrm{F}^{\prime} \times \mathrm{PPFD} \times 0.5 \times 0.84$, where PPFD: photosynthetic photon flux density incident on the leaf, 0.5: a factor that assumes equal distribution of energy between the two photosystems, 0.84: assumed leaf absorbance. Measurements of stomatal conductance and modulated chlorophyll fluorescence were taken after 7 , 14, 21, and 28 days of $\mathrm{NaCl}$ treatment, and 3, 6, 9, and 12 days of $\mathrm{Cd}$ treatment.

\section{Growth Determinations}

At the end of the experimental period, all leaves were detached from the stems and the total leaf area was measured with a Delta $\mathrm{T}$ image analysis system (Delta T, LTD, England, UK). Total leaf dry weight was determined after leaves had been dried at $70^{\circ} \mathrm{C}$ for 48 hours.

\section{Pigments Assay}

$0.5 \mathrm{~g}$ of fresh leaves were ground in $10 \mathrm{ml}$ of $80 \%$ cold acetone. The homogenate was centrifuged at $5,000 \mathrm{x}$ g for $10 \mathrm{~min}$. The supernatant absorbance at 663.2, 646.8, and $470.0 \mathrm{~nm}$ was recorded. Chlorophyll a (Chl a), chlorophyll b (Chl b), and carotenoid contents (mg.g $\left.{ }^{-1} . \mathrm{FW}\right)$ were calculated according to Lichtenthaler [53].

\section{Leaf $\mathrm{Na}^{+}$and $\mathrm{Cd}^{2+}$ Contents}

At harvest, $\mathrm{Na}^{+}$content in the leaf tissues of $\mathrm{NaCl}$ treated plants was measured by flame emission photometry (Eppendorf) after extraction of the dry tissues in $0.1 \mathrm{~N} \mathrm{HNO}_{3}$. To measure $\mathrm{Cd}^{2+}$ in leaves, samples were wet-digested with $\mathrm{HNO}_{3} / \mathrm{HClO}_{4}(4 / 1, \mathrm{~V} / \mathrm{V})$, and the leaf $\mathrm{Cd}^{2+}$ content was determined on the digests with atomic absorption spectrophotometry. All samples were analyzed in duplicate with reagent blanks.

\section{Statistical Analysis}

The effects of the salt and cadmium treatments on all measured physiological parameters were tested using one-way ANOVA. Statistica 7.1 software (Stat-Soft, Inc., Tulsa, OK, USA) was used to perform statistical analyses. Differences between treatments were significant at $\mathrm{p}<0.05$ in the Student-Newman-Keuls test. All results indicate mean values and their standard error $( \pm \mathrm{SE})$.

\section{Results and Discussion}

\section{Leaf Growth and $\mathrm{Na}^{+}$and $\mathrm{Cd}^{2+}$ Contents}

Results showed that leaf dry matter and leaf area of tomato plants decreased with an increase of salt and cadmium stress intensity in the growth medium, and tomato suffered a more serious decrease under $\mathrm{Cd}$ treatments (Table 1). For NaCl-treated plants, higher values of dry matter and leaf area were at $25 \mathrm{mM} \mathrm{NaCl}$, followed by control $(0 \mathrm{mM} \mathrm{NaCl})$. Inhibition of dry matter and leaf area was $80 \%$ after 12 days of growth at $10 \mathrm{mM}$ $\mathrm{Cd}$ and did not exceed $60 \%$ and $72 \%$ for dry matter and leaf area, respectively, after 28 days at $200 \mathrm{mM} \mathrm{NaCl}$. The higher level of growth loss under Cd stress compared to salt stress suggests that $\mathrm{Cd}$ has a greater negative impact on plant health than salt. This could be explained by the high phytotoxicity of $\mathrm{Cd}$, which is not an essential nutrient in higher plants [54]. It has been reported that exposure to even relatively low concentrations of $\mathrm{Cd}$ results in high toxicity to plants [55]. The inhibition of 
growth under stress conditions could be due to alterations in photosynthesis, leaf area expansion, ions imbalance, or disturbances of ion homeostasis. Similar results have been recorded in other species both under salt [56-58] and cadmium [59-61] stresses. Lower accumulation of plant biomass under $\mathrm{NaCl}$ and $\mathrm{Cd}$ treatments is associated with a significant increase of leaf $\mathrm{Na}^{+}$(Fig. 1a) and $\mathrm{Cd}^{2+}$ (Fig. 1b) contents. It was shown that $\mathrm{NaCl}$ and $\mathrm{Cd}$ bring ionic toxicity by elevated levels of $\mathrm{Na}^{+}[28-30]$ and $\mathrm{Cd}^{2+}$ [32-33] in plant tissues, which disturbs nutrient uptake and stomatal opening, inhibits some of the enzymes of the Calvin cycle, and affects plant biomass [62].

\section{Photosynthetic Pigments}

Leaf pigments content is an indicator of general plant health [57]. Our results showed that $\mathrm{NaCl}$ and $\mathrm{Cd}$ induced a significant decrease in chlorophyll content (Table 1). The reductions recorded after $12 \mathrm{~d}$ at $10 \mathrm{mM} \mathrm{Cd}$ were 23,61 ,

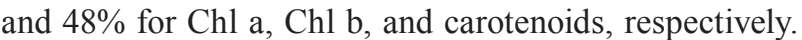
Under $\mathrm{NaCl}$ treatment, the variations measured after 28 days at $200 \mathrm{mM} \mathrm{NaCl}$ showed an increase in carotenoid content by $61 \%$, while chlorophyll content was decreased by $45 \%$ and $63 \%$ for for $\mathrm{Chl}$ a and $\mathrm{Chl} \mathrm{b}$, respectively. The decline in chlorophyll content under stress conditions could be due to impaired biosynthesis or accelerated pigment degradation [63]. Our results are in agreement with those of Bacha et al. [64] and Kaya et al. [65], who
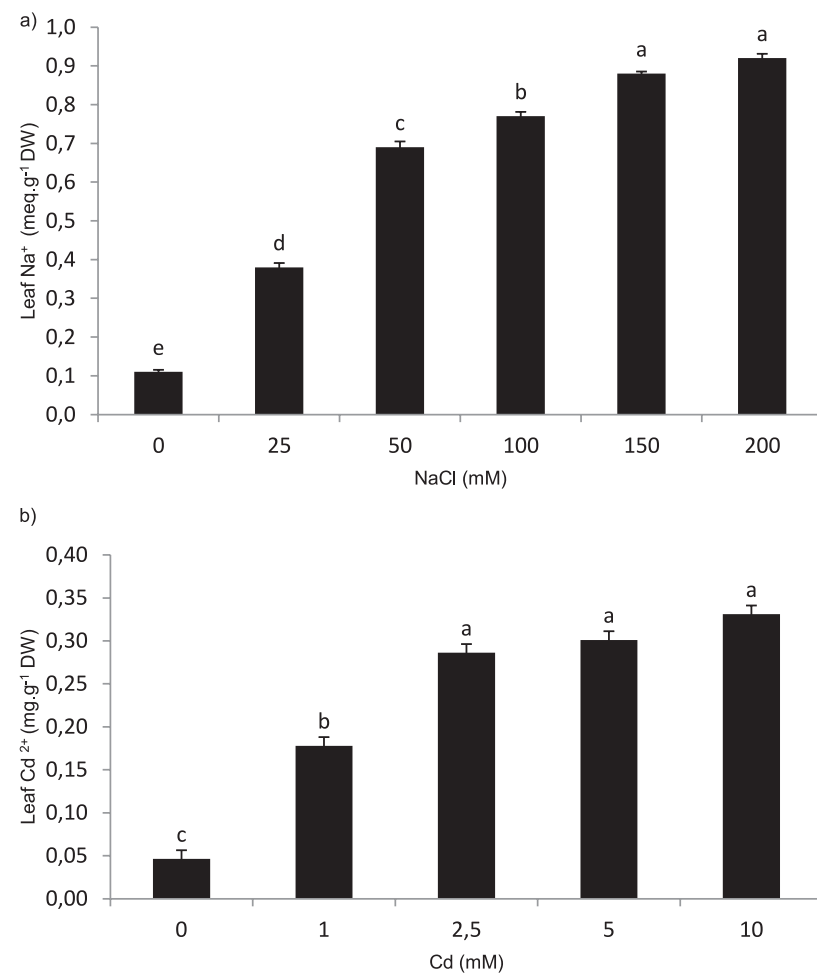

Fig. 1. Accumulation of $\mathrm{Na}^{+}$a) and $\mathrm{Cd}^{2+}$ b) in tomato leaves after exposure to 28 days $\mathrm{NaCl}$ or 12 days $\mathrm{Cd}$ at different concentrations. Bars represent standard deviations of six replicates; values followed by different letters were significantly different $(\mathrm{P}<0.05)$. observed a loss of chlorophyll content in plants subjected to salt stress. The effect is ascribed to an increased level of the toxic cation $\mathrm{Na}^{+}[66]$. On the other hand, carotenoid accumulation is enhanced by $\mathrm{NaCl}$ stress. These results are in agreement with other studies that have reported an increase in carotenoids under salt stress [67-68], presumably due to the protective effect of carotenoids against reactive oxygen species (ROS) [37, 67]. Under $\mathrm{Cd}$ treatments, we recorded a significant decrease in both chlorophyll and carotenoid contents. It was shown that $\mathrm{Cd}$ treatment impairs the structure of chloroplasts, the chlorophyll biosynthesis pathway, and the assembly of the pigment-protein complexes of photosystems [69]. Our results are in agreement with those of Thapar et al. [68] and Chen et al. [70].

\section{Stomatal Conductance}

Under stress conditions, plant growth is affected by stress factors in different ways [71], and the photosynthetic process appears to be particularly sensitive to $\mathrm{NaCl}[72-73]$ and $\mathrm{Cd}[69,74]$. Photosynthesis inhibition may be ascribed to stomatal and/or nonstomatal limitations, [75-76]. The results of our study showed that both $\mathrm{NaCl}$ and $\mathrm{Cd}$ stresses decreased stomatal conductance (Gs). Under salt treatment, Gs decreased progressively with increased $\mathrm{NaCl}$ concentrations (Fig. 2a). The decrease after 28 days of $\mathrm{NaCl}$ treatment was about $82 \%$ and $91 \%$ under 150 and $200 \mathrm{mM} \mathrm{NaCl}$, respectively. The decrease in $\mathrm{Gs}$ in $\mathrm{NaCl}$-treated plants could be due to the decrease of water potential and the concomitant increase in $\mathrm{Na}^{+}$in tomato leaves [73]. The increased accumulation of $\mathrm{Na}^{+}$in the vacuoles could be a strategy for plants to decrease cell water potential under saline conditions [77]. Under Cd treatment, the decline of Gs was drastic and occurred at an early stage, beginning from the lowest $\mathrm{Cd}$ concentration in the growth medium ( $1 \mathrm{mM} \mathrm{Cd}$ ) and continuing to drop throughout the experiment (Fig. 2b). Reduction in Gs after 12 days of cadmium treatments were about $69 \%$ and $78 \%$ under 5 and $10 \mathrm{mM} \mathrm{Cd}$, respectively, and could be ascribed to plant water balance [69]. Closing the stomatal pores and/or decreasing its density have been reported
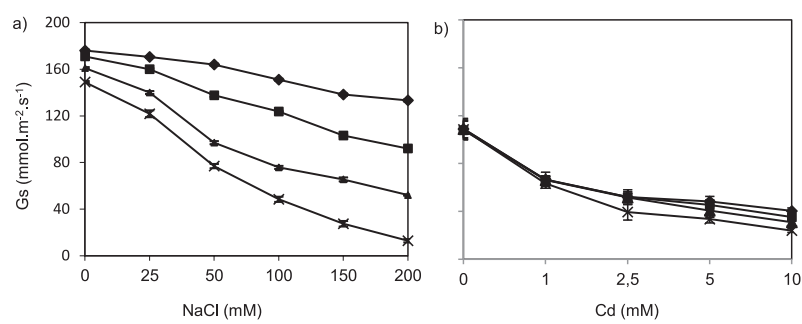

Fig. 2. Changes in stomatal conductance (Gs) of tomato leaves under salt treatments a) after $7 \mathrm{~d}$ (diamonds), $14 \mathrm{~d}$ (squares), 21 $\mathrm{d}$ (triangles), $28 \mathrm{~d}$ (cross); and cadmium treatments b) after 3 $\mathrm{d}$ (diamonds), $6 \mathrm{~d}$ (squares), $9 \mathrm{~d}$ (triangles), and $12 \mathrm{~d}$ (cross). Means \pm SE $(n=4)$. Standard errors are shown when greater than the symbol. 
in other species under salt $[24,31]$ and $\mathrm{Cd}$ treatments [33-34]. The stomatal closures along with reductions in chlorophyll contents suggest that both stomatal and non-stomatal restrictions occurred under $\mathrm{NaCl}$ and $\mathrm{Cd}$ stresses [62].

\section{Steady-State of Dark-Adapted Fluorescence Parameters under Salt and Cadmium Stresses}

$\mathrm{F}_{\mathrm{o}}, \mathrm{F}_{\mathrm{m}}$, and $\mathrm{F}_{\mathrm{v}} / \mathrm{F}_{\mathrm{m}}$ are important $\mathrm{Chl}$ fluorescence parameters used in plant stress physiology studies [78]. $\mathrm{F}_{\mathrm{o}}$ is minimal fluorescence level when all antenna pigment complexes associated with photosystem are open (dark adapted). $F_{m}$ is the maximal fluorescence level when a high intensity flash has been applied. All antenna sites are assumed to be closed [79]. The $\mathrm{F}_{\mathrm{v}} / \mathrm{F}_{\mathrm{m}}$ ratio is an index of the maximum photochemical efficiency of PSII (the efficiency if all PSII centers were open) and can be used to estimate the potential efficiency of PSII by taking dark-adapted measurement [78-79]. A decrease in $\mathrm{F}_{\mathrm{v}} / \mathrm{F}_{\mathrm{m}}$
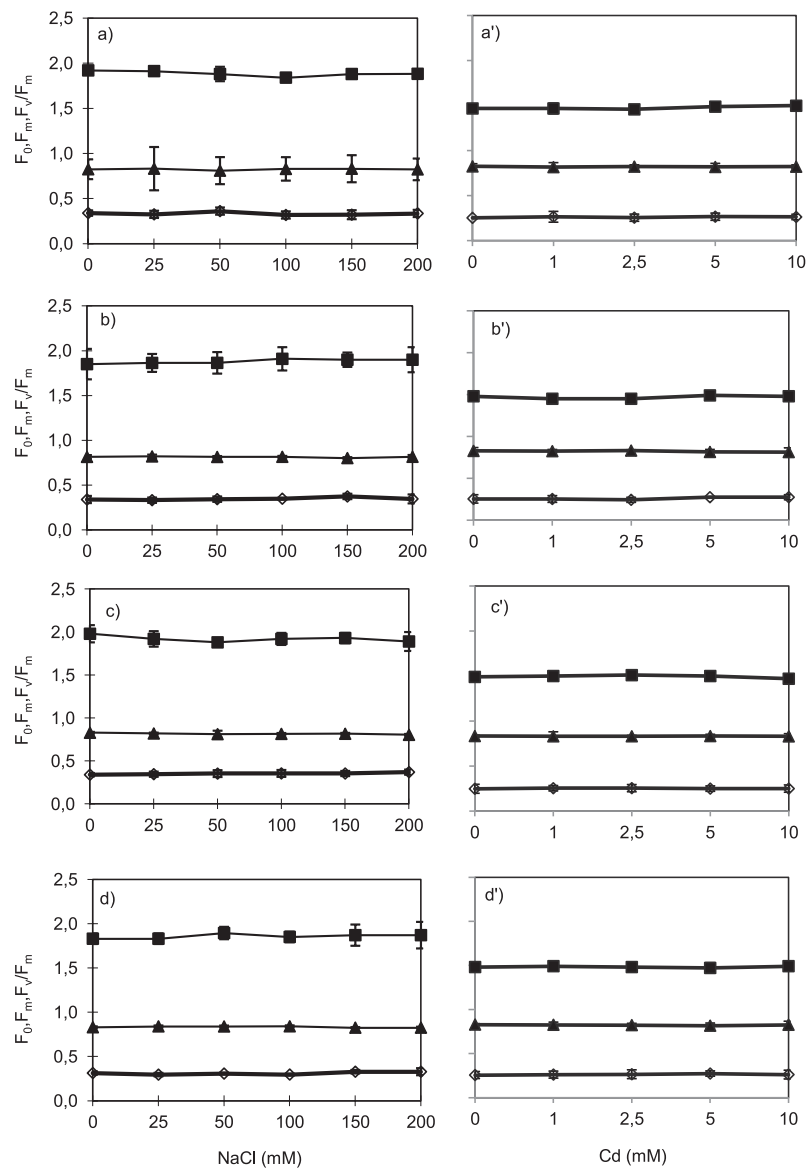

Fig. 3. Changes in the fluorescence measurements of the minimal chlorophyll a fluorescence, $\mathrm{F}_{0}$ (diamonds), maximal $\mathrm{Chl} a$ fluorescence, $\mathrm{F}_{\mathrm{m}}$ (squares), and maximum quantum efficiency of PSII photochemistry, $\mathrm{F}_{\mathrm{v}} / \mathrm{F}_{\mathrm{m}}$ (triangles), and in tomato leaves under salt treatments after $7 \mathrm{~d}$ (a), $14 \mathrm{~d}(\mathrm{~b}), 21 \mathrm{~d}(\mathrm{c})$, and $28 \mathrm{~d}$ (d), and cadmium treatments after $3 \mathrm{~d}\left(\mathrm{a}^{\prime}\right), 6 \mathrm{~d}\left(\mathrm{~b}^{\prime}\right), 9 \mathrm{~d}\left(\mathrm{c}^{\prime}\right)$, and $12 \mathrm{~d}\left(\mathrm{~d}^{\prime}\right)$. Means $\pm \mathrm{SE}(\mathrm{n}=16)$. Standard errors are shown when greater than the symbol. is a reliable sign of photoinhibition [80]. Fig. 3 showed the responses to $\mathrm{NaCl}$ and $\mathrm{Cd}$ stresses of the chlorophyll a fluorescence parameters of dark-adapted leaves of tomato over time. Under $\mathrm{NaCl}$ treatment, there was no change in minimal $\mathrm{Chl}$ fluorescence $\left(\mathrm{F}_{0}\right)$, maximal $\mathrm{Chl}$ fluorescence $\left(\mathrm{F}_{\mathrm{m}}\right)$, and maximum quantum efficiency of PSII photochemistry $\left(\mathrm{F}_{\mathrm{v}} / \mathrm{F}_{\mathrm{m}}\right)$ throughout the time of salt treatment, indicating that salinity did not induce sustained photodamage. The average $\mathrm{F}_{\mathrm{v}} / \mathrm{F}_{\mathrm{m}}$ value was $0.80 \pm 0.01$ for both control and salt-treated plants over the course of the experiment (Figs 3a-d). Other studies showed little to no effect on $\mathrm{F}_{\mathrm{v}} / \mathrm{F}_{\mathrm{m}}$ - even when leaf growth and gas exchange were reduced [81-82]. Under Cd treatment, there were no significant changes in $\mathrm{F}_{0}, \mathrm{~F}_{\mathrm{m}}$ between the control and Cd-treated plants, and plants maintained high $\mathrm{F} / \mathrm{F}_{\mathrm{m}}$ values throughout the experiment even at high $\mathrm{Cd}$ concentrations (Figs 3a'-d'). Nevertheless, $F_{v} / F_{m}$ slightly decreased at the end of the experiment but without statistical significance. The average value of $F_{v} / F_{m}$ was $0.81 \pm 0.01$ for control and treated plants. At the end of the experiment, $\mathrm{F}_{\mathrm{v}} / \mathrm{F}_{\mathrm{m}}$ of $\mathrm{Cd}$-treated plants dropped slightly to 0.78 after $12 \mathrm{~d}$ at $10 \mathrm{mM} \mathrm{Cd}$.

Our results were in agreement with those of Streb et al. [26], who showed that the $\mathrm{F}_{\mathrm{v}} / \mathrm{F}_{\mathrm{m}}$ parameter was not sensitive to $\mathrm{Cd}$ stress. In contrast, other studies showed that the $\mathrm{F}_{\mathrm{v}} / \mathrm{F}_{\mathrm{m}}$ decreased under Cd stress [69-70]. In this experiment, the stability of $\mathrm{F}_{\mathrm{v}} / \mathrm{F}_{\mathrm{m}}$ under $\mathrm{NaCl}$ and $\mathrm{Cd}$ treatments showed that there was no damage to PSII, suggesting that neither stress affected the PSII primary photochemistry, which may not be the first target of $\mathrm{Cd}$ and $\mathrm{NaCl}$ stresses. This is because $\mathrm{NaCl}$ and $\mathrm{Cd}$ initially decrease stomatal conductance, which reduces photosynthesis and growth of the plant, leaving PSII unaffected in the early stages of stress [46].

Light-Adapted Fluorescence Parameters and Photoprotection Mechanisms under Salt and Cadmium Stresses

The actual PSII efficiency $\left(\Phi_{\text {PSII }}\right)$ of light-adapted leaves gives an estimation of the efficiency and represents the photochemistry at different photon flux density [4]. $\Phi_{\text {PSII }}$ depends on (i) the proportion of open oxidized PSII reactions centers estimated by the photochemical quenching $\mathrm{q}_{\mathrm{P}}[48]$ and (ii) the intrinsic PSII efficiency $\left(\Phi_{\text {exc }}\right)$ [49-50]. NPQ (non-photochemical quenching) is the amount of dissipated excessive irradiation into heat and has a role in photoprotection [40]. Therefore, its activity is regulated by environmental conditions [39]. In this experiment the response of light-adapted leaves of tomato differed depending on the stress factor, stress intensity, and time exposure to $\mathrm{NaCl}$ and $\mathrm{Cd}$ stresses. Under salt treatments, fluorescence kinetics showed no significant difference in $\Phi_{\text {exc }}$ and $\Phi_{\text {PSII }}$ for the first three weeks after salt treatment began (Fig. 4a-c). At the end of the fourth week, $\Phi_{\text {exc }}$ and $\Phi_{\text {PSII }}$ decreased significantly (Fig. 4d).

Control plants had an average $\Phi_{\text {exc }}$ value of $0.75 \pm 0.01$ and $\Phi_{\text {PSII }}$ value of $0.61 \pm 0.01$. After 28 days at $200 \mathrm{mM}$ 

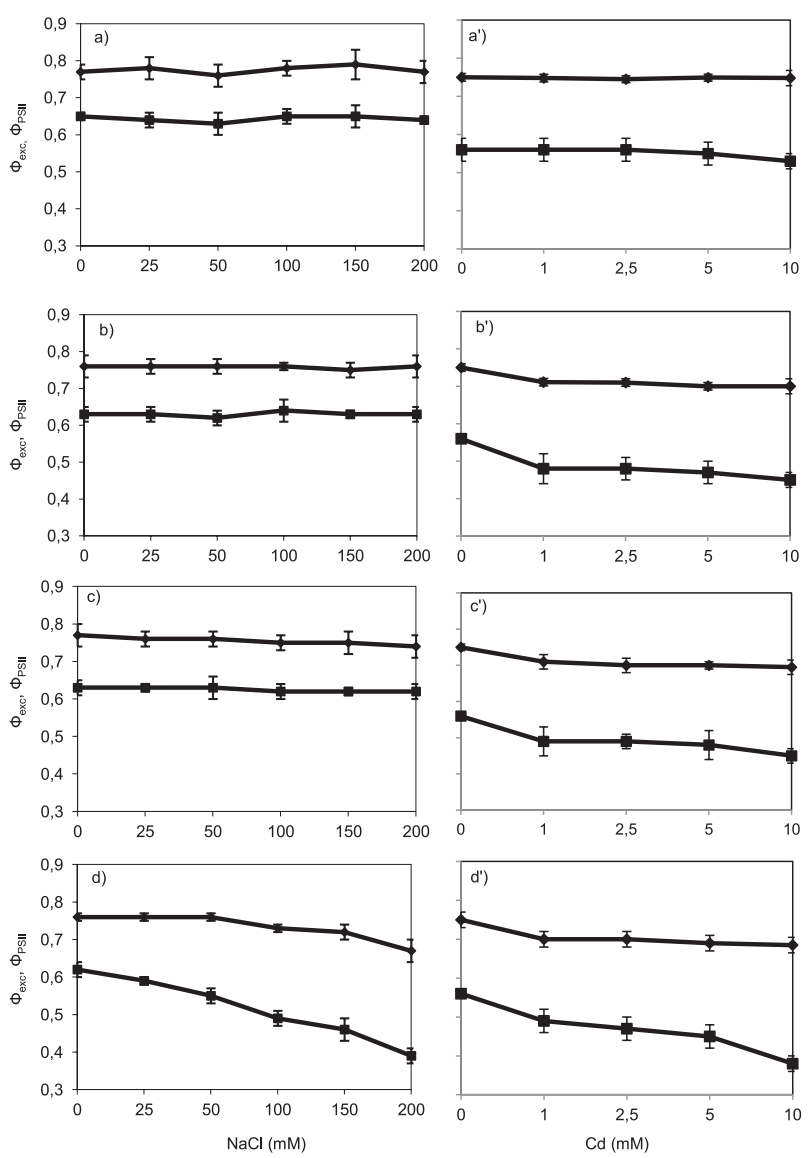

Fig. 4. Changes in the fluorescence measurements of the intrinsic efficiency of open PSII, $\Phi_{\text {exc }}$ (diamonds) and quantum yield of PSII electron transport, $\Phi_{\text {PSII }}$ (squares) in tomato leaves under salt treatments after $7 \mathrm{~d} \mathrm{a}$ ), $14 \mathrm{~d} \mathrm{~b}$ ), $21 \mathrm{~d} \mathrm{c}$ ), and $28 \mathrm{~d} \mathrm{~d}$ ), and cadmium treatments after $3 \mathrm{~d}_{\mathrm{a}}$ '), $6 \mathrm{~d}^{\mathrm{b}}$ '), $9 \mathrm{~d} \mathrm{c}^{\prime}$ ), and $12 \mathrm{~d} \mathrm{~d}^{\prime}$ ). Means \pm SE $(n=16)$. Standard errors are shown when greater than the symbol.

$\mathrm{NaCl}, \Phi_{\text {exc }}$ decreased to $0.67 \pm 0.01$ and $\Phi_{\text {PSII }}$ dropped to $0.32 \pm 0.01$. Under cadmium treatments, the decrease in $\Phi_{\text {exc }}$ and $\Phi_{\text {PSII }}$ occurred at an early stage. Light-adapted parameters declined on day 6 of the cadmium treatment and continued to decrease until the end of the experiment (Figs 4a'-d'). Control plants had an average $\Phi_{\text {exc }}$ value of $0.74 \pm 0.01$ and $\Phi_{\text {PSII }}$ value of $0.56 \pm 0.01$. After $12 \mathrm{~d}$ at $10 \mathrm{mM} \mathrm{Cd}, \Phi_{\text {exc }}$ decreased to $0.68 \pm 0.01$ and $\Phi_{\mathrm{PSII}}$ declined to $0.38 \pm 0.01$.

Lower $\Phi_{\mathrm{PSII}}$ in tomato leaves treated with $\mathrm{NaCl}$ and $\mathrm{Cd}$ implied that the distribution of light energy was reduced. This quenching mechanism was not due to inhibited photochemistry since the $\mathrm{Fv} / \mathrm{Fm}$ ratio remained quite stable (Fig. 3). Under such conditions, increasing NPQ could play a key role in excess energy dissipation in order to keep photosynthetic machinery from being destroyed. Our results indicated that there was no change in NPQ at the beginning of $\mathrm{NaCl}$ (Figs 5a-c) and $\mathrm{Cd}$ ( Figs 5a'-c') treatments. At the end of the experimental period, NPQ rose significantly with increased $\mathrm{NaCl}$ (Fig. 5d) and $\mathrm{Cd}$ (Fig. 5d') stress intensities. This increase was coupled with a significant decrease of $q_{p}$.
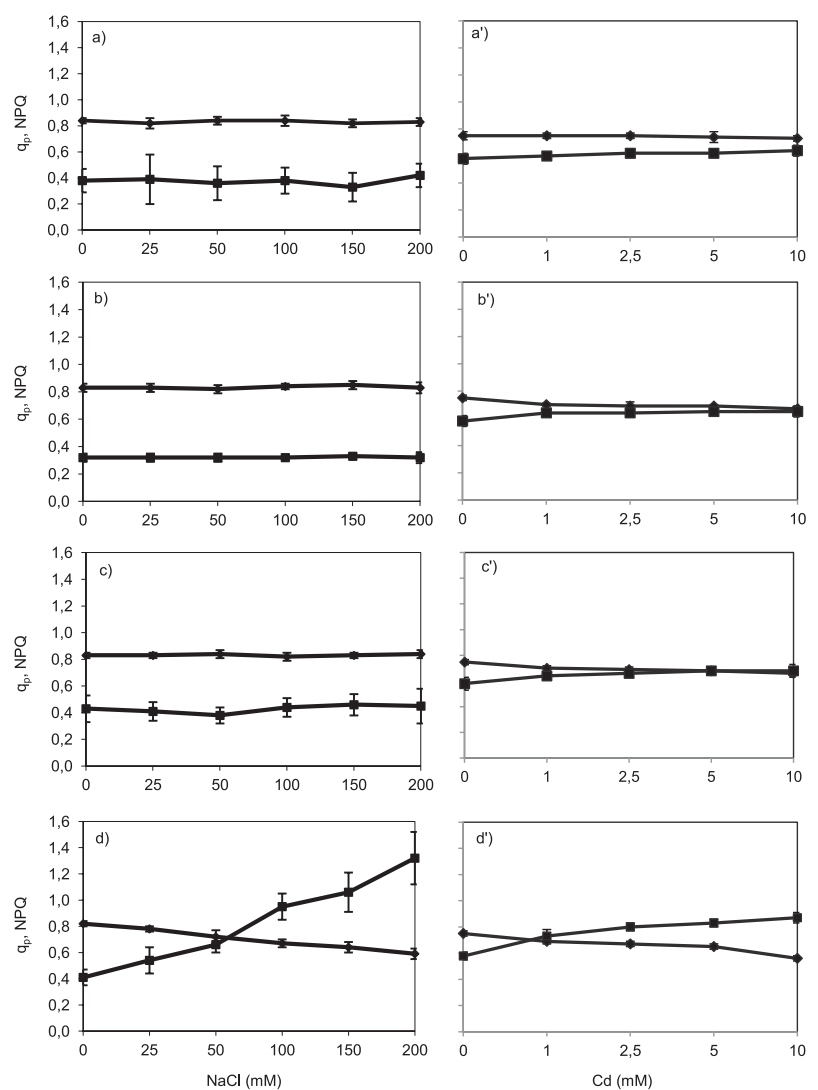

Fig. 5. Changes in the fluorescence measurements of photochemical quenching, $\mathrm{q}_{\mathrm{p}}$ (diamonds) and non-photochemical quenching, NPQ (squares) in tomato leaves under salt treatments after $7 \mathrm{~d} \mathrm{a}$ ), $14 \mathrm{~d} \mathrm{~b}$ ), $21 \mathrm{~d} \mathrm{c}$ ), and $28 \mathrm{~d} \mathrm{~d}$ ), and cadmium treatments after $\left.\left.\left.3 \mathrm{~d}^{\prime} \mathrm{a}^{\prime}\right), 6 \mathrm{~d} \mathrm{~b}^{\prime}\right), 9 \mathrm{~d} \mathrm{c}^{\prime}\right)$, and $\left.12 \mathrm{~d} \mathrm{~d}^{\prime}\right)$. Means \pm SE $(n=16)$. Standard errors are shown when greater than the symbol.

In salt-treated plants, the average NPQ value was $0.41 \pm 0.01$ in control plants which increased to $1.30 \pm 0.01$, whereas $\mathrm{q}_{\mathrm{p}}$ values decreased from $0.8 \pm 0.01$ in control plants to $0.58 \pm 0.01$ by $28 \mathrm{~d}$ at $200 \mathrm{mM} \mathrm{Nacl}$. In Cd-treated plants, the average NPQ value was $0.58 \pm 0.01$ in control plants, which increased to $0.87 \pm 0.01$ while $\mathrm{q}_{\mathrm{p}}$ values were $0.75 \pm 0.01$ in control plants and decreased to $0.56 \pm 0.01$ by $12 \mathrm{~d}$ at $10 \mathrm{mM} \mathrm{Cd}$. The decrease of $q_{p}$ along with an increase of NPQ may cause a down regulation of PSII to avoid over-reduction of $Q_{A}$ [49]. Such control serves as a dissipation mechanism for the excessive excitation energy when the rate of ATP and NADPH synthesis exceeds demands [38]. It has been shown that environmental stresses make the electron transfer chain saturated and increase proton accumulation, therefore NPQ would increase [39, 80]. The highest NPQ was obtained in NaCl-treated plants. This indicates the ability of tomato leaves to dissipate more excess energy, which provides a higher ability to mitigate the negative effects of $\mathrm{NaCl}$ treatments at the chloroplast level, as these organelles have the ability to dissipate the excess excitation energy [63]. The increased capacity of NPQ has been reported for other species under both salt $[67,83]$ and $\mathrm{Cd}[54,69]$ treatments. In $\mathrm{NaCl}$-treated 

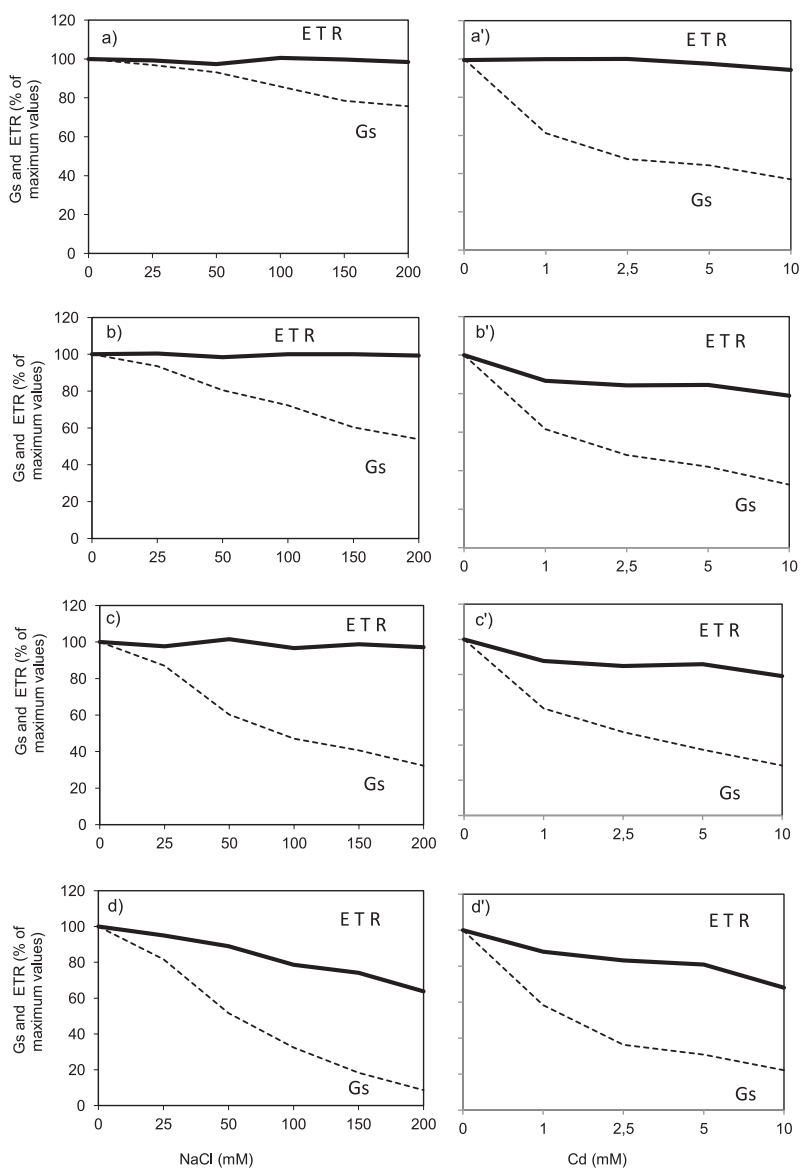

Fig. 6. Progression of electron transport rate (ETR) and stomatal conductance (Gs) under salt treatments after $7 \mathrm{~d} \mathrm{a}$ ), $14 \mathrm{~d} \mathrm{~b}$ ), $21 \mathrm{~d} \mathrm{c}$ ), and $28 \mathrm{~d} \mathrm{~d}$ ), and cadmium treatments after $3 \mathrm{~d} \mathrm{a}^{\prime}$ ), $6 \mathrm{~d}^{\prime}$ '), $\left.9 \mathrm{~d} \mathrm{c}^{\prime}\right)$, and $\left.12 \mathrm{~d} \mathrm{~d}^{\prime}\right)$. Means $\pm \operatorname{SE}(\mathrm{n}=16)$.

plants, the increased NPQ activity could be related to the increase in carotenoid content [80,84-85]. The increase in carotenoid accumulation under salt stress and its decrease under $\mathrm{Cd}$ stress suggests that regulation of NPQ by salt and cadmium was obtained by different mechanisms $[80,84]$. In addition to enhanced thermal dissipation, increased photorespiration may be a potential mechanism for avoiding photodamage in salt-stressed plants [38-39]. The photosynthetic parameter ETR provides a conjecture of the rate of electrons pumped via the PSII into the photosynthetic chain [86]. Therefore, malfunctioning of the ETR undeniably implies that there is damage to the PSII. In our experiment, the primary response of tomato leaves to salt (Figs 6a-c) and cadmium (Fig. 6a') was a decrease in stomatal conductance with no change in photosynthetic performance and electron transport rate. After 28 days at $200 \mathrm{mM} \mathrm{NaCl}$, Gs decreased by about 91\% and ETR by $36 \%$ (Fig. 6d). Under Cd treatment, Gs decreased by $78 \%$ and ETR by $21 \%$ and $32 \%$ at days 9 and 12, respectively (Figs 6c'-d'). This suggests that $\mathrm{NaCl}$ and $\mathrm{Cd}$ initially decreased stomatal conductance, leaving PS II unaffected in the early stages of stress [46, 72]. By the end of the experiment, the quasi total stomatal closure with $91 \%$ and $78 \%$ reduction of $\mathrm{Gs}$ under $\mathrm{NaCl}$ and $\mathrm{Cd}$ stress, respectively, were accompanied by a decline in ETR. Hence, stomatal closure is associated with a downregulation of ETR, which is compensated for by increased thermal dissipation. In an attempt to investigate the most reliable $\mathrm{Chl}$ a fluorescence parameters for measuring sensitivity of tomato to cadmium and salinity, a multiple correlation analysis was performed between $\mathrm{Chl}$ a fluorescence characteristics and leaf $\mathrm{Na}^{+}$and $\mathrm{Cd}^{2+}$ contents (Table 2). Results showed a significant positive correlation with NPQ and significant negative correlations (about 0.9) with $\Phi_{\text {PSII }}, q_{p}$, and ETR. These parameters could be considered as an indicator of photosynthetic disturbance in tomato leaves. Similar conclusions have been reported for Atriplex halimus and costal plants under cadmium [69] and salt [72] stress, respectively.

\section{Conclusions}

In the present study, we evaluated the effect of salinity and cadmium treatments on growth and photosynthetic parameters of tomato plants. Exposure of tomato to $\mathrm{NaCl}$ and $\mathrm{Cd}$ considerably affected its growth expressed as dry

Table 2. Pearson's correlation coefficients between $\mathrm{Chl}$ a fluorescence parameters and $\mathrm{Na}^{+}$and $\mathrm{Cd}^{2+}$ contents (upper and lower triangle, respectively) in tomato leaves under salt and cadmium treatments.

\begin{tabular}{|c|c|c|c|c|c|c|c|}
\hline & $\mathrm{Na}^{+}$ & $\mathrm{F}_{\mathrm{v}} / \mathrm{F}_{\mathrm{m}}$ & $\Phi_{\text {PSII }}$ & $\mathrm{q}_{\mathrm{p}}$ & $\mathrm{NPQ}$ & $\Phi_{\text {exc }}$ & ETR \\
\hline $\mathrm{Cd}^{2+}$ & 1 & -0.82 & -0.96 & -0.97 & 0.93 & -0.81 & -0.94 \\
\hline $\mathrm{F}_{\mathrm{v}} / \mathrm{F}_{\mathrm{m}}$ & -0.72 & 1 & 0.34 & 0.99 & -0.34 & 0.39 & 0.96 \\
\hline$\Phi_{\text {PSII }}$ & -0.93 & 0.89 & 1 & 0.85 & -0.99 & 0.89 & 0.99 \\
\hline $\mathrm{q}_{\mathrm{p}}$ & -0.92 & 0.83 & 0.98 & 1 & -0.98 & 0.86 & 0.99 \\
\hline $\mathrm{NPQ}$ & 0.86 & -0.89 & -0.89 & -0.81 & 1 & -0.94 & -0.99 \\
\hline$\Phi_{\text {exc }}$ & -0.67 & 0.93 & 0.79 & 0.69 & -0.92 & 1 & 0.93 \\
\hline $\mathrm{ETR}$ & -0.94 & 0.89 & 0.99 & 0.98 & -0.89 & 0.78 & 1 \\
\hline
\end{tabular}

$\mathrm{F}_{\mathrm{v}} / \mathrm{F}_{\mathrm{m}: \mathrm{s}}$ maximum quantum efficiency of PSII; $\Phi_{\mathrm{PSII}}$ : quantum yield of PSII photochemistry; $\mathrm{q}_{\mathrm{p}}$ : photochemical quenching; NPQ: nonphotochemical quenching; $\Phi_{\text {exc }}$ : intrinsic efficiency of PSII; ETR: electron transport rate. Probabilities $(P \leq 0.05)$. 
mass and leaf area, photosynthetic pigment concentrations, stomatal conductance, and photochemical apparatus (PSII). $\mathrm{NaCl}$ and $\mathrm{Cd}$ stresses induced significant effects on chlorophyll fluorescence. The decreases in $\Phi_{\mathrm{PSII}}$ and increases in NPQ with no decline in $\mathrm{F}_{\mathrm{v}} / \mathrm{F}_{\mathrm{m}}$ is an adaptative response preparing plants to dissipate excess light as heat to avoid photodamage. Light-adapted fluorescence measurements showed that $\Phi_{\text {PSII }}, \mathrm{q}_{\mathrm{p}}$, ETR, and NPQ are the better indicators for detecting salt and cadmium stresses before severe damage occurs in tomato plants.

\section{Acknowledgements}

This study was supported by the University of Science of Tunis (FST) and the National Research Institute of Rural Engineering Water and Forests (INRGREF), Tunisia. Special thanks are due to the staff of the Laboratory of Environmental Risk Management in Irrigated Agriculture at the INRGREF institute for technical assistance. We are thankful to Madam Christie Chaar for correcting the English language of the manuscript.

\section{References}

1. MUNNS R., TESTER M. Mechanisms of salinity tolerance. Annu. Rev. Plant Biol. 59, 651, 2008.

2. MANSOUR M.M.F., ALI E.F. Glycinebetaine in saline conditions: an assessment of the current state of knowledge. Acta Physiol. Plant. 39, 56, 2017

3. JI P., SUN T., SONG Y., ACKLAND M.L., LIU Y. Strategies for enhancing the phytoremediation of cadmiumcontaminated agricultural soils by Solanum nigrum L. Environ Pollut. 159, 762, 2011.

4. CI D., JIANG D., WOLLENWEBER B., DAI T., JING Q., CAO W. Cadmium stress in wheat seedlings: growth, cadmium accumulation and photosynthesis. Acta Physiol. Plant. 32, 365, 2010.

5. ZEMANOVA V., PAVLÍK M., PAVLÍKOVA D., HNILICKA F., VONDRACKOVA S. Responses to Cd stress in two noccaea species (Noccaea praecox and Noccaea caerulescens) originating from two contaminated sites in Mezica, Slovenia and Redlschlag, Austria. Arch. Environ. Contam. Toxicol. 70, 464, 2016.

6. GILL S.S., KHAN N.A, TUTEJA N. Differential cadmium stress tolerance in five Indian mustard (Brassica juncea L.) cultivars: an evaluation of the role of antioxidant machinery. Plant Signal Behav. 6, 293, 2011.

7. FERNÁNDEZ R., BERTRAND A., REIS R., MOURATO M.P., MARTINS L.L., GONZÁLEZ A. Growth and physiological responses to cadmium stress of two populations of Dittrichia viscosa (L.) Greuter. J. Hazard Mater. 244, 555, 2013

8. KHAN A.L., WAQAS M., HUSSAIN J., AL-HARRASI A., LEE I.J. Fungal endophyte Penicillium janthinellum LK5 can reduce cadmium toxicity in Solanum lycopersicum (Sitiens and Rhe). Biol. Fertil. Soils. 50, 75, 2014.

9. DA SILVA A.J.C.W.A., DO NASCIMENTO A., DA SILVA C.W.A., GOUVEIA-NETO A., DA SILVA JR E.A. LED-Induced chlorophyll fluorescence spectral analysis for the early detection and monitoring of cadmium toxicity in maize plants. Water Air Soil Pollut. 22, 3527 , 2012.

10. LI S., YANG W., YANG T., CHEN Y., NI W. Effects of cadmium stress on leaf chlorophyll fluorescence and photosynthesis of Elsholtzia argyi a cadmium accumulating plant. Int. J. Phytorem. 17, 85, 2015.

11. MITTELSTET A.R., STORM D., STOECKER A., Using SWAT and empirical relationship to simulate crop yields and salinity levels in the North Fork River Basin. International Journal of Agricultural and Biological Engineering. 8, 1, 2015.

12. FLOWERS T.J., MUNNS R., COLMER T.D. Sodium chloride toxicity and the cellular basis of salt tolerance in halophytes. Annals of botany. 115, 419, 2015.

13. GUPTA N.K., MEENA S.K., GUPTA S., KHANDELWAL S.K. Gas exchange, membrane permeability and ion uptake in two species of Indian Jujube differing in salt tolerance. Photosynthetica. 40, 535, 2002.

14. AKRAM M.S., ASHRAF M., SHAHBAZ M., AKRAM N.A. Growth and photosynthesis of salt-stressed sunflower (Helianthus annuus) plants as affected by foliar-applied different potassium salts. J. Plant Nutr. Soil Sci. 172, 884, 2009.

15. CIOBANU I., SUMALAN R. The effects of the salinity stress on the growing rates and physiological characteristics to the Lycopersicum esculentum Species. Bulletin UASVM Horticulture. 66, 616, 2009.

16. MEGDICHE W., HESSINI K., GHARBI F., JALEEL C.A., KSOURI R., ABDELLY C. Photosynthesis and photosystem 2 efficiency of two salt-adapted halophytic seashore Cakile maritima ecotypes. Photosynthetica. 46, 410, 2008.

17. MANAN A., AYYUB C.M., PERVEZ M.A., AHMAD R. Methyl jasmonate brings about resistance against salinity stressed tomato plants by altering biochemical and physiological processes. Pakistan Journal of Agriculture Sciences. 53, 35, 2016.

18. MEHTA P., KRASLAVSKY V., BHARTI S., ALLAKHVERDIEV S.I., JAJOO A. Analysis of saltstress induced changes in photosystem II heterogeneity by prompt fluorescence and delayed fluorescence in wheat (Triticum vulgare) leaves. Journal of Photochemistry and Photobiology B: Biology. 104, 308, 2011.

19. MAXWELL K., JOHNSON G. N. Chlorophyll fluorescence as practical guide. J. Exp. Bot. 51, 659, 2000.

20. FLEXAS J., MEDRANO H. Energy dissipation in C3 plants under drought. Functional Plant Biology. 29, 1209, 2002.

21. BRESSON J., VASSEUR F., DAUZAT M., KOCH G., GRANIER C., VILE D. Quantifying spatial heterogeneity of chlorophyll fluorescence during plant growth and in response to water stress. Plant Methods. 11, 1, 2015.

22. FU W., LI P., WU Y. Effects of different light intensities on chlorophyll fluorescence characteristics and yield in lettuce. Sci. Hortic. 135, 45, 2012.

23. HU H., ZHANG H., CHU J., ZHANG X., ZHENG K., LI S., SUN X., ZHANG X. Leaf chlorophyll fluorescence effect of different rice (Oryza sativa L.) genotypes under salt stress. Adv. Sci. Lett. 11, 706, 2012.

24. ASKRI H., GHARBI F., REJEB S., MLIKI A., GHORBEL A. Identification du mécanisme physiologique de tolérance à la salinité chez la vigne sauvage Vitis vinifera. ssp. Sylvestris. Revue des Regions Arides. 35, 739, 2014.

25. LABIDI N., AMMARI M., SNOUSSI S., MESSELINI N., GHARBI F., ABDELLY C. Stimulated growth rate by restriction of $\mathrm{P}$ availability at moderate salinity but 
insensitive to $\mathrm{P}$ availability at high salinity in Crithmum maritimum. Acta Biologica Hungarica. 62, 302, 2011.

26. STREB P., AUBERT S., GOUT E., FEIERABEND J., BLIGNY R. Cross tolerance to heavy-metal and coldinduced photoinhibiton in leaves of Pisum sativum acclimated to low temperature. Physiol. Mole. Biol. Plants. 14, 185, 2008.

27. DUNWEI C.I., JIANG D., WOLLENWEBER B., DAI T., JING Q., CAO W. Cadmium stress in wheat seedlings: growth, cadmium accumulation and photosynthesis. Acta Physiol. Plant. 32, 365, 2010.

28. ZHANG J.T., MU C.S. Effects of saline and alkaline stresses on the germination, growth, photosynthesis, ionic balance and antioxidant system in an alkali-tolerant leguminous forage Latyrus quenquenervius. Soil Sci. Plant Nut. 55, 685, 2009.

29. CHAVES M.M., FLEXAS J., PINHEIRO C. Photosynthesis under drought and salt stress: regulation mechanisms from whole plant to cell. Ann. Bot. 103, 551, 2009.

30. GIANNAKOULA A.E., ILIAS I.F. The effect of water stress and salinity on growth and physiology of tomato (Lycopersicon esculentum Mill.). Arch. Biol. Sci. Belgrade. 65, 611, 2013.

31. HEIDARI A., BANDEHAGH A., TOORCHI M. Effects of $\mathrm{NaCl}$ Stress on Chlorophyll Content and Chlorophyll Fluorescence in Sunflower (Helianthus annuus L.) lines. YYU. J. Agr. Sci. 24, 111, 2014.

32. MOHAMED A.A., CASTAGNA A., RANIERI A., SANITA DI TOPPI L. Cadmium tolerance in Brassica juncea roots and shoots is affected by antioxidant status and phytochelatin biosynthesis. Plant Physiol. Biochem. 57, 15,2012

33. GILL S.S., KHAN N.A., TUTEJA N. Differential cadmium stress tolerance in five Indian mustard (Brassica juncea L.) cultivars: an evaluation of the role of antioxidant machinery. Plant Signal Behav. 6, 293, 2011.

34. FERNÁNDEZ R., BERTRAND A., REIS R., MOURATO M.P., MARTINS L.L., GONZÁLEZ A. Growth and physiological responses to cadmium stress of two populations of Dittrichia viscosa (L.) Greuter. J. Hazard Mater. 244, 555, 2013.

35. KHAN A.L., WAQAS M., HUSSAIN J., AL-HARRASI A., LEE I.J. Fungal endophyte Penicillium janthinellum LK5 can reduce cadmium toxicity in Solanum lycopersicum (Sitiens and Rhe). Biol. Fertil. Soils. 50, 75, 2014.

36. AVENSON T.J., AHN T.K., ZIGMANTAS D., LIZ K.K., BALLOTTARI M. Zeaxanthin radical cation formation in minor light-harvesting complexes of higher plant antenna. J. Biol. Chem. 283, 3550, 2008.

37. CAZZONELLI C.I., POGSON B.J. Source to sink: regulation of carotenoid biosynthesis in plants. Trends Plant Sci. 15, 266, 2010.

38. MURCHIE E.H., NIYOGI K.K. Manipulation of Photoprotection to Improve Plant Photosynthesis. Plant Physiology. 155, 86, 2011.

39. LAMBREV P.H., MILOSLAVINA Y., JAHNS P., HOLZWARTH A.R. On the relationship between non-photochemical quenching and photoprotection of Photosystem II. Biochim. Biophys. Acta. 1817, 760, 2012.

40. PINNOLA A., DALL'OSTO L., GEROTTO C., MOROSINOTTO T., BASSI R., ALBORESI A. Zeaxanthin binds to light-harvesting complex stress-related protein to enhance non photochemical quenching in Physcomitrella patens. Plant Cell. 25, 3519, 2013.

41. LI Q., DENG M., XIONG Y., COOMBES A., ZHAO W. Morphological and photosynthetic response to high and low irradiance of Aeschynanthus longicaulis. Sci. World J. 2014, 1, 2014.

42. HADDAD M., BOUKRIS M. The effect of geothermal water on quality of tomatoes. In: Proceedings of the International Workshop Mednine, Tunisia. 156, 1999.

43. HACHICHA M. Les sols sales et leur mise en valeur en Tunisie. Secheresse. 18, 45, 2007.

44. KAHLAOUI B., HACHICHA M., TEIXEIRA J., MISLE E., FIDALGO F., HANCHI, B. Response of two tomato cultivars to field-applied proline and salt stress. Journal of Stress Physiology and Biochemistry. 9, 357, 2013.

45. MONTEITH J. L., CAMPBELL G. S., POTTER E. A. Theory and performance of a dynamic diffusion porometer. Agric. For. Meteorol. 44, 27, 1988.

46. BAKER N.R., ROSENQVIST E. Applications of chlorophyll fluorescence can improve crop production strategies: an examination of future possibilities. J. Exp. Bot. 55, 1607, 2004.

47. BJÖRKMAN O., DEMMIG-ADAMS B. Regulation of photosynthetic light energy capture, conversion, and dissipation in leaves of higher plants. In: Schulze, E.D., Caldwell, M.M. (Eds.), Ecophysiology of Photosynthesis. Springer-Verlag, Berlin. 17, 1994.

48. VAN KOOTEN O., SNEL J. F. H. The use of chlorophyll fluorescence nomenclature in plant stress physiology. Photosynth. Res. 25, 147, 1990.

49. GENTY B., BRIANTAIS J.M., BAKER N.B. The relationship between the quantum yield of photosynthetic electron transport and quenching of chlorophyll fluorescence. Biochim. Biophys. Acta. 99, 87, 1989.

50. HARBINSON J., GENTY B., BAKER N. B. Relationship between the quantum efficiencies of photosystems I and II in pea leaves. Plant Physiol. 90, 1029, 1989.

51. SCHREIBER U., BILGER W., NEUBAUER C. Chlorophyll fluorescence as a non invasive indicator for rapid assessment of in vivo photosynthesis. In: Schulze, E.D., Caldwell, M.M. (Eds.), Ecophysiology of Photosynthesis. Springer-Verlag, Berlin-Heidelberg-New York. 49, 1995.

52. KRALL J.P., EDWARDS G.E. Relationship between photosystem II activity and $\mathrm{CO}_{2}$ fixation in leaves. Physiol. Plant. 86, 180, 1992.

53. LICHTENTHALER H.K. Chlorophylls and carotenoids: pigments of photosynthetic biomembranes. Methods Enzymol. 148, 350, 1987.

54. WANG Y., JIANG X., LI K., WU M., ZHANG R., ZHANG L., CHEN G. Photosynthetic responses of Oryza sativa L. seedlings to cadmium stress: physiological, biochemical and ultrastructural analyses. Biometals. 27, 389, 2014.

55. REDENDO-GOMEZ S., MATEOS NARANGO E., ANDRADES MORENO L. Accumulation and tolerance characteristics of cadmium in halophytic $\mathrm{Cd}$ hyperaccumulator Anthrocnemum macrostachium. J. Hasard Mat. 184, 299, 2010.

56. ALI S., CHARLES C.T., GLICK R.B. Amelioration of high salinity stress damage by plant growth-promoting bacterial endophytes that contain ACC deaminase. Plant Physiology and Biochemistry. 80, 160, 2014.

57. MANAN A., CHOUDHARY M.A., AHMAD R., ADNAN M., BUKHARI M.A., MUSTAFA Z. Salinity Induced Deleterious Effects on Biochemical and Physiological Processes of Tomato. Pak. J. Life Soc. Sci. 14, 83, 2016.

58. AL-HARBI A.R., AL-OMRAN A.M., ALENAZI M.M., WAHB-ALLAH M.A. Salinity and deficit irrigation influence tomato growth, yield and water use efficiency at different developmental stages. Int. J. Agri. Bio. 17, 241, 2015. 
59. COSTA, A.C., REZENDE-SILVA S.L., MEGGUER C.A., MOURA L.M.F., ROSA M., SILVA A.A. The effect of irradiance and water restriction on photosynthesis in young jatoba-do-cerrado (Hymenaea stigonocarpa) plants. Photosynthetica. 53, 118, 2015.

60. GILL S.S., KHAN N.A., TUTEJA N. Differential cadmium stress tolerance in five Indian mustard (Brassica juncea L.) cultivars: an evaluation of the role of antioxidant machinery. Plant Signal Behav. 6, 293, 2011.

61. KHAN A.L., WAQAS M., HUSSAIN J., AL-HARRASI A., LEE I.J. Fungal endophyte Penicillium janthinellum LK5 can reduce cadmium toxicity in Solanum lycopersicum (Sitiens and Rhe). Biol. Fertil. Soils. 50, 75, 2014.

62. CARMO-SILVA A.E., GORE M.A., ANDRADESANCHEZ P., FRENCH A.N., HUNSAKER D.J., SALVUCCI M.E. Decreased $\mathrm{CO}_{2}$ availability and inactivation of Rubisco limit photosynthesis in cotton plants under heat and drought stress in the field. Environmental and Experimental Botany. 83, 1, 2012.

63. SAKURABA Y., LEE S.H., KIM Y.S., PARK O.K., HORTENSTEINER S., PAEK N.C. Delayed degradation of chlorophylls and photosynthetic proteins in Arabidopsis autophagy mutants during stress-induced leaf yellowing. J. Exp. Bot. 65, 3915, 2014.

64. BACHA H., TEKAYA M., DIRINE S., GUASMI F., TOUIL L., ENNEB H., TRIKI F., CHEOUR T. F., FERCHICHI A. Impact of salt stress on morpho-physiological and biochemical parameters of Solanum lycopesicum cv Microtom leaves. South African journal of Botany. 108, 364, 2016.

65. KAYA C., ASHRAF M., SONMEZ O., AYDEMIR S., TUNA A.T., CULLU M.A. The influence of arbuscular mycorrhizal colonisation on key growth parameters and fruit yield of pepper plants grown at high salinity. Scientia Horticulturae. 121, 1, 2009.

66. YANG C.Z., YANIGER S.I., JORDAN V.C., KLEIN D.J., BITTNER G.D. Most plastic products release estrogenic chemicals: a potential health problem that can be solved. Environmental Health Perspectives. 119, 989, 2011.

67. AZZABI G., PINNOLA A., BETTERLE N., BASSI R., ALBORESI A. Enhancement of Non-Photochemical Quenching in the Bryophyte Physcomitrella patens During Acclimation to Salt and Osmotic Stress. Plant Cell Physiol. 53, 1815, 2012.

68. THAPAR R., KUMAR SRIVASTAVA A., BHARGAVA P., MISHRA Y., CHAND RAI L. Impact of different abiotic stresses on growth, photosynthetic electron transport chain, nutrient uptake and enzyme activities of $\mathrm{Cu}$-acclimated Anabaena doliolum. Journal of Plant Physiology. 165, 306, 2008.

69. MESNOUA M., MATEOS-NARANJO E., BARCIAPIEDRAS J.M.J., PEREZ-ROMERO A., LOTMANI B., REDONDO-GOMEZ S. Physiological and biochemical mechanisms preventing Cd-toxicity in the hyperaccumulator Atriplex halimus L. Plant Physiology and Biochemistry. 106, 30, 2016.

70. CHEN L., LONG X.H., ZHANG Z.H., ZHENG X.T., RENGEL Z., LIU Z.P. Cadmium accumulation and translocation in two Jerusalem Artichoke (Helianthus tuberosus L.) cultivars. Pedosphere. 21, 573, 2011.

71. GHARBI F., REJEB S., GHORBAL M. H., MOREL J. L. Plant response to copper toxicity as affected by plant species and soil type. Journal of Plant Nutrition. 28, 379, 2005.
72. NAUMANN J.C., YOUNG D.R., ANDERSON J.E. Linking leaf chlorophyll fluorescence properties to physiological responses for detection of salt and drought stress in coastal plant species. Physiol. Plant. 131, 422, 2007.

73. ZRIBI L., GHARBI F., REZGUI F., REJEB S., NAHDI H., REJEB M.N. Application of chlorophyll fluorescence for the diagnosis of salt stress in tomato Solanum lycopersicum (variety Rio Grande). Sci. Hortic. 120, 367, 2009.

74. CI D., JIANG D., WOLLENWEBER B., DAI T., JING Q., CAO W. Cadmium stress in wheat seedlings: growth, cadmium accumulation and photosynthesis. Acta Physiol. Plant. 32, 365, 2010.

75. AI-ABDOULHADI I.A., DINAR H.A., EBERT G., BÜTTNER C. Influence of salinity stress on photosynthesis and chlorophyll content in date palm. Afr. J. Agric. Res. 7, 3314, 2012.

76. MURILLO-AMADOR B., REYES-PÉREZ J.J., HERNÁNDEZ-MONTIEL L.G., RUEDA-PUENTE E. O., DE LUCIA B., BELTRÁN-MORALES F.A., RUIZESPINOZA F.H. Physiological responses to salinity in Solanum lycopersicum 1. varieties. Pak. J. Bot. 49, 809, 2017.

77. FLOWERS T.J., MUNNS R., COLMER T.D. Sodium chloride toxicity and the cellular basis of salt tolerance in halophytes. Annals of Botany. 115, 419, 2015.

78. MURCHIE E.H., LAWSON T. Chlorophyll fluorescence analysis: a guide to good practice and understanding some new applications. J. Exp. Bot. 64, 3983, 2013.

79. GORBE E., CALATAYUD A. Applications of chlorophyll fluorescence imaging technique in horticultural research: a review. Sci. Hortic. 138, 24, 2012.

80. PORCAR-CASTELL A., TYYSTJARVI E., ATHERTON J., VAN DER TOL C., FLEXAS J., PFÜNDEL E. E., MORENO J., FRANKENBERG C., BERRY J. A. Linking chlorophyll a fluorescence to photosynthesis for remote sensing applications: mechanisms and challenges. J. Exp. Bot. 65, 4065, 2014.

81. SELLAMI R., GHARBI F., REJEB S., REJEB M.N., HENCHI B., ECHEVARRIA G., MOREL J.L. Effects of Nickel Hyperaccumulation on Physiological Characteristics of Alyssum murale Grown on Metal Contaminated Waste Amended Soil. Int. J. Phytoremed. 14, 609, 2012.

82. NASRAOUI-HAJAJI A., GHARBI F., GHORBEL M.H., GOUIA H. Cadmium stress effects on photosynthesis and PSII efficiency in tomato grown on $\mathrm{NO}^{-}$or $\mathrm{NH}^{+}$as nitrogen source. Acta Bot. Gallica. 157, 101, 2010.

83. STEPIEN P., JOHNSON G.N. Contrasting responses of photosynthesis to salt stress in the glycophyte Arabidopsis and the halophyte Thellungiella: role of the plastid terminal oxidase as an alternative electron sink. Plant Physiol. 149, 1154, 2009.

84. NIYOGI K.K., SHIH C., CHOW W.S., POGSON B.J., DELLA PENNA D., BJORKMAN O. Photoprotection in a zeaxanthin- and lutein-deficient double mutant of Arabidopsis. Photosynth. Res. 67, 139, 2001.

85. ISMAIL I.M., BASAHI J.M., HASSAN I.A. Gas exchange and chlorophyll fluorescence of pea (Pisum sativum L.) plants in response to ambient ozone at a rural site in Egypt. Sci. Total Environ. 497, 585, 2014.

86. MARTINS S.C.V., GALMES J., MOLINS A., DAMATTA F.M. Improving the estimation of mesophyll conductance to $\mathrm{CO}_{2}$ : on the role of electron transport rate correction and respiration. J. Exp. Bot. 64, 3285, 2013. 